\section{CASCO BIZTOSÍTÁSI CSALÁSOK KÖZGAZDASÁGI MODELLJE}

Lakatos Máté MSc (Aegon Magyarország Általános Biztositó Zrt., aktuárius) lkt.mate@gmail.com

\section{ÖSSZEFOGLALÓ}

A tanulmány a biztosítási csalások elméleti modellezésével foglalkozik. A dolgozat legfőbb célja egy olyan, Magyarországon kiemelkedően fontos és népszerű casco-csalás elméleti modelljének megalkotása, amelyben az egyén köt egy casco biztosítást, majd „ellopatja” az autóját, és kárbejelentést tesz. A tanulmány legfőbb hozzájárulása, hogy korábbi, általános csalási szituációt vizsgáló modellekből kiindulva megalkot egy, a magyar piacon leginkább megfigyelhető csalási formát leíró elméleti modellt, amelynek alapján több hasznos és nem triviális megállapítás tehető a casco-csalások természetére, az egyes ösztönzők csalási valószínűségre gyakorolt hatására vonatkozóan. A játékelméleti eszközökkel megalapozott modell megoldásaként kapott eredmény kitér az önrész nem egyértelmű hatására, a csaló esetleges büntetésének marginális szerepére és a sikeres felderítési valószínűség kiemelkedő szerepére a csalás megfékezését illetően. Bevezetve azt a feltevést, hogy a büntetés az eladott autó értékével egyezik meg, egyrészt megállapítható, hogy a csalás valószínűsége növekszik az autó életkorának növekedésével, másrészt pedig nem feltétlenül alátámasztott azon vélekedés, hogy az értékesebb autók esetén növekedne a csalási valószínűség.

\section{SUMMARY}

An Economic Model of CASCO Insurance Fraud

In this paper, a theoretical model is presented for a 'Hungarian specific' insurance fraud in the field of automobile insurance. This type of CASCO insurance fraud which covers to theft of a car in order to obtain the sum assured, dominates the Hungarian automobile insurance market. After introduction of general model the Hungarian automobile market is introduced in particular with regard to CASCO market and CASCO frauds. The main result of the study is providing a model for the presented type of insurance fraud based on earlier model from Picard. It can be observed the adversary impact of deductible, the marginal effect of penalty amount, and the importance of successful detecting probability in terms of fraud elimination. Using a condition where the penalty in case of detecting the fraudulent claim is equal to the value of sold car on the secondary market, it can be concluded that the probability of fraud increases as the age of the car is higher. On the other hand it is not demonstrated that the more valuable car raises the probability of fraud.
Kulcsszavak: biztosítási csalás; casco biztosítás; antiszelekció; nem tökéletes információs játék

Keywords: insurance fraud; CASCO insurance; adverse selection; imperfectinformation games

JEL: D82

DOI: $10.18530 / B K .2016 .58$

http://dx.doi.org/1018530/BK.2016.2.58

\section{Bevezetés ${ }^{1}$}

„Vélhetöen az első biztositási szerződés megkötése után el is követték az elsö biztositási csalást.” - így fogalmazott Trunkó Barnabás, a MABISZ egykori fötitkára. Az állítás elsődleges célja, hogy felhívja a figyelmet a biztosítási csalások jelenlétére és fontosságára, ami kellő motivációt ad a tanulmánynak a tekintetben, hogy ez egy releváns, létező, de a világ talán egyetlen biztositási piacán sem megoldott probléma. Országonként eltérő mértékben ugyan, de a kárbejelentések jelentős hányadában történik valamilyen értelemben vett csalás.

Világszinten a statisztikák szerint az összes bejelentett káresemény 14 százaléka esetében valamilyen biztosítási csalás történik, és Magyarországon is több tízmilliárd forintot tesznek ki a jogtalan kárkifizetések (Generali, 2010). A csalási gyakoriság iparági szinten Magyarországon is hasonló mértékű, 10-15 százalék körül alakul becslések szerint, természetesen szegmensenként eltér, de szakemberek szerint a gépjármű-biztosítási csalások a leggyakoribbak (Biztosítási Szemle, 2015a).

\section{Világszinten a káresemény 14 százaléka esetében valamilyen}

biztosítási csalás történik.

A tanulmányban a magyar casco biztosítási csalások elméleti modellezésével foglalkozom: a közgazdaságtan, azon belül a mikroökonómia elmélet és a játékelmélet eszköztárával modellezem a hazai piacokon elérhető casco biztosítási termékek esetén fellelhető „tipikus” csalási formát, az autó ellopásának szimulálását az ügyfél (csaló) részéről, amikor is a szerződő a casco megkötése után lopáskárt jelent be a biztosítási összeg megszerzése céljából, miközben az autót értékesíti a másodlagos piacon. Ennek megfelelően a tanulmány központi kérdése, hogy milyen ösztönzőkkel, eszközökkel lehet képes a biztosító a csalás mértékét csökkenteni vagy megszüntetni?

Fontos hangsúlyozni, hogy a tanulmány nem egy empirikus adatokon nyugvó elemzés, hanem elméleti modellt épít, így a dolgozat elsődleges célja az említett csalási formát leíró 
modell kidolgozása és az ebből származó következtetések levonása, nem pedig statisztikai eredmények megfogalmazása.

A tanulmányban elsőként bemutatásra kerülnek azok a legfontosabb elméleti és gyakorlati eredmények, amelyek tetszőleges biztosítási csalási szituációt vizsgáltak, ezáltal relevánsnak tekinthetők a tanulmány szempontjából. Hosszabban szót ejtek Picard (1996) általános csalási szituációt vizsgáló elméleti modelljéről, amely kiindulási alapja lesz a későbbiekben épített modellemnek. A harmadik fejezetben rátérek a gépjármü-biztosítási csalásokra. Először kiemelem a biztosítási piacok különbözőségét, fókuszálva a gépjármü-biztosításokra, majd leírom ezen eltérések okait. E jelentős eltérések miatt nevezhető ugyanis a tanulmány hiánypótlónak, hiszen Magyarországon az eddigiekben nem született a gépjármü-biztosítások vizsgálatával - különösen elméleti szinten - foglalkozó elemzés, a más országokra kiélezett modellek pedig nem alkalmazhatóak a magyarországi piacra.

A negyedik fejezetben a korábban bemutatott eredmények alapján alkotok egy elméleti modellt, amely nem általánosan, hanem a Magyarországon gyakori casco biztosítási csalás esetén írja le a szereplők közötti kapcsolatot és a csalási valószínűségre ható legfontosabb tényezőket. A modell felépítése után teszek egy rövid játékelméleti kitekintést, majd ezt felhasználva felírom a játékfát, amelynek alapján megfelelően szemléltethető a játék menete, lefolyása. Úgy gondolom, ez szükséges ahhoz, hogy megfelelő keretekben kezelhessem a problémát, és áttekinthető maradjon a modellem.

Ezt követően levonom a modellből származó következtetéseket, és teszek néhány fontos észrevételt, amelyek a gyakorlatra is érvényesek lehetnek. Eszerint bemutatom az önrész kettős szerepét, amely a csalási valószínűségre direkt és indirekt módon is hat ellenkező irányból, ezáltal elméleti szinten nem egyértelmű ezen ösztönző eredő hatása a csalásokra. Kiemelem a csaló számára kirótt büntetés marginális szerepét a csalási valószínűség szempontjából, valamint a sikeres felderítés szerepét, mint a legfontosabb tényezőt a csalás megszüntetése szempontjából. További feltevésekkel élve megfogalmazom a modell alapján azt az állítást, hogy nem kimondottan a nagy értékű autók esetén jellemző a vizsgált csalási forma.

\section{A biztosítási csalások elméleténekáttekintése}

\section{Biztositási csalások fajtái}

Mielőtt kitérnék a biztosítási csalásokkal kapcsolatos modellek taglalására, elsőként azt kell definiálni, hogy közgazdasági értelemben mit érthetünk biztosítási csalás alatt. Nem triviális ugyanis, hogy mi tekinthető biztosítási csalásnak, és mi nem, a legfontosabb pedig, hogy több fajtája létezik, éppen ezért egyértelműen meg kell jelölni azt, amellyel a továbbiakban foglalkozik a tanulmány. Biztosítási csalás alatt olyan tevékenységet értünk, amelynek során a szerződő erőfeszítést tesz a (nagyobb) kártérítés megszerzése végett, és amely erőfeszítés bebizonyosodása esetén a biztosító mentesül a kárkifizetés alól. Talán az előző mondat is sugallja, de kiemelten fontos megkülönböztetni az erkölcsi kockázat efféle megjelenési formáját és a biztosítási csalást (Ágoston, 2004). Erkölcsi kockázat alatt azt értjük ebben az esetben, hogy a szerződő viselkedése megváltozik a biztosítás megkötése után. Jó példa erre, hogy egy lopáskárt is fedező casco biztosítás megkötését követően az egyén könnyebben otthagyja az autóját egy kevésbé biztonságos helyen, azonban ez még nem tekinthető csalásnak.

A biztosítási csalás esetében az egyén szándékosan segíti elő a (nagyobb) kár bekövetkezését, ideértve például a fiktív vagy magasabb összegű számlával igazolt káreseményt is. Crocker és Morgan (1998) a következőképpen választotta szét e tevékenységeket: build-up fraud és outright-fraud. Találó magyar fordítása nincs a két angol kifejezésnek, de értelemszerűen a build-up csalás az enyhébb szint, amely abban nyilvánul meg, hogy a szerződő felnagyítja úgymond a véletlenül bekövetkezett kár mértékét a nagyobb kártérítés érdekében. Maradva a gépjármü-biztosításoknál, ide tartozik például a valódi kár mértékénél nagyobb összegű számla bemutatása a szerződő részéről. A második szint tulajdonképpen a valódi csalás (outright fraud), melynek esetében a biztosított egy nem létező vagy éppen egy szándékosan megrendezett káresemény révén szeretne hozzájutni a biztosítási összeghez. Az outright fraud-on belül Weisberg és Derrig (1998) megkülönböztetik még az opportunista (opportunistic fraud) és a tervezett csalást (planned fraud). Az első esetben a szerződő csupán megragadja az alkalmat egy káresemény bekövetkezésekor, és további kárt okoz, például egy autó törésekor tovább töri az adott alkatrészt a gépjárműben. Ezzel szemben a tervezett csalás esetében már maga a károkozás is kitervelt módon történik, azaz az elsődleges kár bekövetkezése sem véletlen esemény. A bemutatott csalási formák közül a tanulmány részletesen a tervezett csalás jelenségével foglalkozik, amikor a károkozás kitervelten és szándékosan történik, haszonszerzés céljából, a build-up típusú csalás mindössze említés szinten jelenik meg a tanulmány későbbi fejezetében.

\section{Elméleti eredmények a csalások modellezésében}

A nemzetközi irodalomban számos tanulmány foglalkozik a biztosítási piacok, azon belül a csalások elméleti és gyakorlati elemzésével. Köszönhető ez annak, hogy a biztosítási piacok jellemzően antiszelekciós jelenséggel terhelt piacok, és a morális kockázat (moral hazard) jelensége is jól azonosítható, ezáltal a mikroökonómia elmélet eszköztárának jó alkalmazási lehetőséget teremt. Jól alátámasztja a fenti állítást, hogy Rothschild és Stiglitz (1976) mérföldkőnek számító modellje is a biztosítási piacon keresztül szemlélteti az antiszelekciós jelenséget, akár csak Holmström (1979) és Shavell (1979) korai modellje, akik az önrész hatását elemzik az antiszelekció szempontjából.

\section{A piacokon gyökeresen eltérő csalási típusokat figyelhetünk meg.}

A biztosítási csalások modellezését illetően számos eredményt és modellt említhetnénk, amelyek nagy jelentőséggel bírtak a tudományos diskurzusban, itt azonban csak a tanulmány 
szempontjából elengedhetetlen eredményeket taglaljuk. Ennek megfelelően leginkább a gépjármü-biztosítási piaccal kapcsolatos tanulmányokat vesszük számba, holott adott országokban nem csak a gépjármü biztosítási csalások a jellemzőek. Artís et al. (1998) szerint az Egyesült Államokban például kimondottan magas az egészségbiztosítási piacon elkövetett csalás, részben a finanszírozási rendszerből fakadóan (lásd például Sparrow 1996a, 1996b Farber et al. 1997). Ezzel szemben Európában, de különösen Magyarországon ez kevésbé jellemző a kvázi ingyenes tb-rendszernek és a marginális méretű egészségbiztositási piacnak köszönhetően. De még adott szegmensen belül, jelen esetben a gépjármü-biztosítások esetében is igaz az, hogy az egyes piacok igen eltérőek, országról országra különbözőek. Különböznek a piacon lévő termékek, a szabályozó jogrendszer, sőt még az emberek csalási viselkedései is. Ezek persze összefüggenek bizonyos mértékben, vagyis a piacokon lévő termékek és azok tulajdonságai nagyban meghatározzák a csalási formákat, azaz gyökeresen eltérő csalási típusokat figyelhetünk meg az egyes piacokon.

Elsőként Weisberg és Derrig $(1991,1992)$ próbálta megmérni és számszerűsíteni a gépjármü-biztosítási csalások jelenlétét, illetve a csalások megszüntetése esetén tehető díjcsökkentés mértékét Massachusetts állam autópiacán. Építve a Weisberg és Derig (1991, 1992) által kínált elméleti keretre, a gépjármü-biztosítási csalást és annak hatását, valamint nagyságrendjét vizsgálta a kanadai piacon Dionne és Belhadji (1996). Figyelemre méltó eredményre jutottak: elemzésük szerint a biztosító oldaláról csalásnak vélt esetek 93 százalékban nem kerültek felülvizsgálatra - adott esetben büntetőeljárás alá -, 59 százalékban a megfelelő bizonyíthatóság hiányában. E tekintetben felülvizsgálat alatt érti a szakirodalom azt a biztosítói tevékenységet, amikor a biztosító megalapozottan gyanítja a csalást, ezért megtagadja a kárkifizetést, és vizsgálatot indít a csalás bizonyítására.

Ezen meglepő számadatoknak egyik lehetséges oka a szerzők szerint a károk alacsony értéke - azaz a biztosító számára nem kifizetődő a vizsgálódás - és a felülvizsgálat relatív magas költsége. Ennek következtében a biztosítók magasabb önrésszel reagáltak a jelenségre a szerzők tapasztalatai alapján, a hatékony felderítés irányába tett kísérlet helyett. Caron és Dionne (1997), felhasználva az említett eredményt, kísérletet tett a sikeres csalásfelderítési arány megbecslésére. Eszerint a biztosítók csalás esetén átlagosan a felülvizsgált esetek mindössze 33 százalékában tudják csak bizonyítani a csalás létét, aminek számos lehetséges oka lehet, következménye pedig a már említett alacsony felülvizsgálati arány.

A csalások megértésével és megmérésével foglalkozó tanulmányok sorát Derrig et al. (1994) tanulmányával zárhatjuk, akik viselkedési faktorokkal próbálták magyarázni és feltárni a csalások természetét, keresve ezzel egyidejűleg a biztosító helyes reakcióját. Eredményük szerint hatékonyabb büntetési metódus kialakítása szükséges a piacon, ami részben a szabályozó felelőssége. A biztosítók pedig hatékonyabban tudják a szerzők szerint a csalásokat kezelni egy közös intézmény felállításával, erre jó példa az Egyesült Államok piacán azóta már müködő csalás elleni intézmény, a Coalition Against Insurance Fraud (CAIF).

Szintén a felülvizsgálati hajlandóság és a felülvizsgálati költség hatását vizsgálta Bond és Crocker (1997), valamint Crocker és Tennyson (1999), de szerződéselméleti szempontból, keresve azt az optimális szerződést, amellyel a biztosító reagálhat a korlátozott felülvizsgálati képességére, ami a relatíve magas árból fakad. Úgy vélem, a bemutatott eredmények is jól szemléltetik a gépjármü-biztosítási csalások mértékét és jelenlétét a piacon, így érthető, hogy az elméleti és gyakorlati tanulmányok legfőbb célkitűzései mind a csalás megértésére, megmérésére és a hatások feltárására irányultak, hiszen ezen területek együttes felhasználásával lehet csak megszüntetni azt.

A csalások mikroökonómiai modellezésében egyik legjelentősebbnek Picard (1995, 1996) elméleti modellje tekinthető, amely számos későbbi elemzés, köztük jelen tanulmány alapjául is szolgált.

\section{A biztosító elköteleződése a feluilvizsgálat iránt képes redukálni} a csalást.

Picard $(1995,1996)$ egy olyan antiszelekciós jelenséggel terhelt modellt mutat be, amelyben a biztosítottak egy része csal, a másik pedig nem, és természetesen a biztosító nem tudja, hogy az adott egyén melyik csoportot képviseli. A biztosító döntési változója ebben az esetben a bejelentett káresemény felülvizsgálata, amely költséggel jár a biztosító számára. Ebben a keretben Picard (1996) arra a kérdésre keresi a választ, hogy a biztosító, valamint a biztosítási piac számára milyen stratégia tekinthető optimálisnak a biztosító részéről. Az elméleti modell eredményeképpen az az állítás fogalmazható meg, hogy amennyiben a biztosító nem köteleződik el a károk felülvizsgálata mellett - azaz a csaló a szerződés megkötésekor nem tudja biztosan a felülvizsgálat tényét -, úgy jelentős lehet a jóléti veszteség, amely akár a piac megszűnéséhez is vezethet a díj emelkedésén keresztül (lásd például Perry 1992). Ebből következően Picard (1996) megmutatja, hogy a biztosító elköteleződése a felülvizsgálat iránt képes redukálni a csalást, amely még hatékonyabb lehet a biztosítók összefogásával, adott esetben egy, a biztosítók által közösen működtetett ellenőrzési intézmény felállításával, ami említésre került a fentiekben is.

Eltérő keretet alkot Andersson és Skogh (2003), ugyanakkor Picard (1996) elemzéséhez hasonlóan a biztosítói elköteleződés hatását vizsgálja és hangsúlyozza. Ismételt játék (repeated game) keretében arra az eredményre jutnak, hogy kellően nagy felülvizsgálati valószínűség esetén a csalás megszüntethető, ennek részben feltétele viszont a szerződővel szemben a szerződés záradékában lefektetni az esetleges nem szerződésnek megfelelő viselkedés következményeit. Fontos azonban kiemelni, Andersson és Skogh (2003) vagyon- és felelősségbiztosításra specifikált modellt épített, míg Picard (1996) általános modellt alkot a csalások kezelésére, függetlenül attól, hogy milyen típusú a csalási probléma. Leginkább ennek köszönhető, hogy számos későbbi tanulmány támaszkodott Picard (1996) általános modelljére, és emiatt foglalkoztunk az irodalmi áttekintés során is részletesebben az ő modelljével, ugyanis az általa kínált mikroökonómia elméleti keret jó alapot ad a tanulmánynak a magyar piacon fellelhető casco-csalási forma modellezéséhez.

Ennek megfelelően több tanulmányhoz hasonlóan jelen modell is Picard (1996) keret- 
rendszerére épül, annak egy adott példára specifikált változata, noha a két tanulmány célja és eredménye különböző.

\section{A gépjármü-biztosítási csalásokról röviden}

Ahogyan a tanulmány korábbi részében hangsúlyoztam, a biztosítási piacok országonként eltérőek, ennek megfelelően még a gépjármü-biztosítási szegmensben is eltérő termékek alakultak ki az egyes piacokon, amire eltérő csalási formákkal reagáltak a tisztességtelen ügyfelek. Némileg folytatva az irodalmi áttekintést, azonban leginkább a piacok különbözőségére fókuszálva ismertetek néhány példát, amely alátámasztja az előző állításomat, ugyanis a tanulmány motivációja éppen a „tipikus” magyar csalási forma modellezése, amely ezáltal önálló modellezési keretet kíván.

A kanadai piacon részben Picard (1996) modelljére építve vizsgálja a csalás természetét Dionne és Gagné (2002) olyan biztosítási termék esetében, amely rendelkezik értékcsökkenési jóváhagyással (replacement cost endorsement), azaz a biztosítási összeg a tartam során mindvégig az új autó értékének megfelelő. Ezen termék esetében a szerzők azt találják, hogy a lopáskár kimondottan a későbbi években figyelhető meg, ahogyan az autó aktuális értéke egyre messzebb kerül a biztosítási összegtől.

Ami a spanyol gépjármű-biztosítási piacot illeti, jellemző csalási forma egy gépjármű többszörös bebiztosítása (Artís et al. 1999). Ebben az esetben ugyan könnyen fel lehetne deríteni a csalást - ahogy azt a szerzők megjegyzik - egy közös adatbázissal, azonban ennek hiányában különösen az alacsonyabb kártartományokban nincs ilyen jellegű ellenőrzés a spanyolországi biztosítók részéről.

A német gépjármű-biztosítási piacot vizsgálja Spindler et al. (2012), ahol a kötelező gépjármü-felelösségbiztosítás (KFZ-Haftpflicht) mellett kétfajta casco köthető, részleges (Teilkasko) és teljes (Vollkasko). Az előbbi nem térít közúti baleset esetén, csak egyéb károkat fedez, míg utóbbi értelemszerűen mindenre kiterjedő fedezetet nyújt, ugyanakkor a kötelező biztosításhoz hasonló bónusz-málusz rendszerrel működik a termék. Ebben az esetben azt figyelik meg a szerzők, hogy a teljes casco esetén még az aszimmetrikus információ sem lelhető fel, szemben a részleges cascóval, ami elsősorban a bónusz-málusz rendszernek köszönhetö.

Érdemes megemlíteni még Dionne és Gagné (2001) empirikus elemzését, akik a build-up típusú csalás és az önrészes biztosítás kapcsolatát vizsgálták. Ebben az esetben - számos egyéb mellett - azt találták, hogy bizonyos esetben a nagyobb önrész képes eliminálni azokat a típusú csalásokat, amelyek az ügyfél által nagyobb kárigény benyújtásában merülnek ki. E gondolatmenet logikusnak tűnik, hiszen amennyiben az ügyfél is megfelelő mértékben részesedik a kárból, úgy nem feltétlen éri meg számára nagyobb kárt bejelenteni.

Kérdés ugyanakkor, hogy ez valóban teljesül-e a magyar piacon? Magyarországon a casco biztosításhoz levonásos és százalékos önrész tartozik, azonban egy kártartományban mindenképpen egy rögzített összeg az önrész. Ebben az esetben viszont igenis létezhet build-up típusú csalás, mivel egy adott szintig - az önrész paramétereitől függően - mindenképpen rögzített a szerződő hozzájárulása, vagyis a bejelentett károk a build-up típusú csalás esetén a kártartomány felső végéhez közelítenek, azaz semmiképpen sem egy kárnagyságra jellemző eloszlást - például Lognormális, Gamma, Pareto - kapunk. Ezt mindenképpen érdemes tesztelni a gyakorlatban, ugyanis érdekes eredményre juthatunk, amely ellentmond Dionne és Gagné (2001) más piacon levont elméleti állításának.

\section{Nem lehet a küilönböző piacokon tett megállapításokat egy másikra alkalmazni.}

Részben az érdekesség kedvéért, részben pedig azért kerültek e példák a gondolatmenetbe, hogy egyértelművé váljon: az egyes jogi vagy termékbeli sajátosságok gyökeresen megváltoztatják az eredményeket, így nem lehet a különböző piacokon tett megállapításokat egy másikra alkalmazni, ugyanis az eltérő szabályok és eltérő termékek eltérő típusú csalást eredményeznek, amelyeket különböző modellekkel lehet megfogni. Éppen ezek azok az okok, amelyek létjogosultságot adnak a tanulmánynak, hogy magyar keretek közötti modellt építsen, amely a magyar piacon elkövetett csalásokat modellezi. Ugyanis kijelenthetö, hogy ebben a tekintetben elméleti szinten nem született kimondottan ezzel a témával foglalkozó tanulmány, legfeljebb érintőlegesen találkozhatunk a magyar biztosítási piacon elkövetett csalások említésével az egyes tanulmányokban.

A magyar gépjármü-biztosítási piac hasonló több európai, elsősorban a német gépjármü-biztosítási piachoz. Ennek megfelelően minden, a törvényben foglalt (2009. évi LXII. törvény) gépjárműre kell kötni egy kötelező felelősségbiztosítást, amely az egyén által másnak okozott károkat fedezi. Ezen felül azonban lehetöség van casco biztosítás kötésére, amely az egyén saját, a gépjárműjében okozott kárai mellett az egyéb okból bekövetkezett károkat is fedezi. Magyarországon a casco-lefedettség 20 százalék körül mozog, vagy inkább az alatt van (Biztosítási Szemle, 2012, 2015b), ami nemzetközi összehasonlításban is alacsonynak számít a hasonló gazdasági teljesítménnyel rendelkező országokhoz képest. Ez természetesen számos egyéb tényezőre, leginkább talán a magasnak mondható, 15 százalékos biztosítási adóra vezethető vissza. Ezzel együtt a korábbi években több okból kifolyólag, de csökkentek a casco biztosításokból származó díjbevételek - hosszú idő után elöször a 2014-es évben látszódott némi emelkedés a casco-piacon dijbevétel oldalon (MABISZ, 2015) -, a csalások száma azonban nem csökkent jelentősen. Sőt, Horváth László, a Generali biztosító vizsgálati csoportjának vezetője szerint a gazdasági válság megnövelte a csalások számát Magyarországon, ugyanakkor az egyes biztosítási szegmensek között a gépjármü-biztosítások esetében a leginkább előforduló esemény a csalás.

\section{A gazdasági válság megnövelte a csalások számát.}

Magyarországon a legkiemelkedőbb casco-csalás (a számtalan többi mellett) a 90-es években történt (Generali, 2010): 1994-től kezdődően 2 év alatt több mint 500 autólopást 
jelentettek be, és 1995-ben már 6 százalékos volt a lopásgyakoriság. A biztosító vizsgálatot indított, melynek során rájöttek, hogy javarészt fiktív autólopásokról volt szó, ahol az autót külföldre vitték értékesíteni, vagy szétszerelték, és alkatrészként értékesítették. A rendőrség 60 ember ellen folytatott nyomozást, melynek során az autók 10 százalékát megtalálták. A következő évben már csak 1 százalék volt a lopásgyakoriság. A fiktív autólopás mellett a megrendezett balesetek számítanak még a szokványos esetekhez (Generali, 2010). Természetesen ezek a csalási típusok fellelhetők más országokban is, azonban a tanulmány célja ennek a példának, mint az egyik leggyakoribb magyar csalási típusnak az elméleti modellezése.

Ami a gyakorlati oldalt illeti, a legtöbb biztosítótársaság az elmúlt időszakban tett lépéseket adatbányászati, csalásfelderítő programok terén, azonban ezek többnyire belső próbálkozások voltak, amelyek így kevésbé összehasonlíthatóak, elemezhetőek, és ami a legfontosabb, kevésbé értékelhetőek iparági szinten. Mindezek mellett született a közelmúltban kimondottan csalások felderítésére, előrejelzésére specifikált program a SPSS Clementine Consulting és a Deloitte Magyarország részéről is, amelyek valamelyest sztenderd keretet kínálnak a csalásfelderítésre (Deloitte, 2009). Ezek az algoritmusok jellemzően mély adatelemzésre épülnek, bizonyos ismérvek alapján képesek felismerni a problémás eseteket. Ilyen alapvető ismérvek, amelyek kimondottan a csalás gyanúját vetik fel, a következők:

- Rövid biztosítási időszak a kárérték keletkezését megelőzően

- Szokatlanul hosszú időtartam a kárérték keletkezése és a bejelentés között.

- A biztosítási fedezet közelmúltbeli jelentős bővítése.

- A biztosítás közelmúltbeli csökkentése kikövetkeztethetően egyfajta káreseményre. Szokatlanul kis számú sérülés egy járművön.

Forrás: SPSS

Látható tehát, hogy a gyakorlati megvalósítás kimondottan a felismerésre és előrejelzésre fókuszál, így azt mondhatjuk, hogy az elméleti modellezése a magyar biztosítási piacon fellelhető csalásoknak minden szempontból új területnek számít. Kérdés azonban, hogy mindez mennyire járulhat hozzá a gyakorlati probléma minél tökéletesebb megoldásához? Ha valóban sikerül feltárni a folyamatokat, modellezni a szereplők viselkedéseit, és ezek valóban érvényesülnek a gyakorlatban - amit egy empirikus elemzés könnyen alátámaszthat -, akkor mindenképpen azt állíthatjuk, hogy a tanulmány eredménye hozzájárulhat a jövőbeli erőfeszítések sikerességéhez.

\section{A magyarországi casco-csalás elméleti modellje}

Az általunk említett és vizsgálandó szituációban elsőként feltesszük, hogy tervezett csalásról van szó. Ez azt jelenti, hogy a biztosított szándékosan okoz kárt az autója fiktív ellopásával. Így a tanulmány központi kérdése az, hogy van-e olyan szituáció a magyar szabályozási és gyakorlati feltételeket figyelembe véve, amely képes a csalást az elméleti modellben valamelyest csökkenteni vagy megszüntetni? Másképpen fogalmazva: megéri-e a biztosítónak, tud-e a biztosító, és ha igen, milyen eszközökkel fellépni a csaló ügyfelek ellen abban az esetben, amikor ezzel a tipikusnak nevezhető egyik leggyakoribb csalási formával állunk szemben? A kérdés megválaszolásához az irodalmi áttekintésben ismertetett mikroökonómia elméleti modellekre, különösen Picard (1996) keretrendszerére támaszkodunk. Kiindulva az említett modellből, számos változtatást - olykor egyszerűsítést vagy bővítést - hajtunk végre, hogy a modell az említett csalási formát írja le, a megfelelő változókkal.

\section{IA biztosított szándékosan okoz kárt az autója fiktív ellopásával.}

Tegyük fel, hogy a biztosított minden esetben kockázatkerülő, és a szokásos Neumann-Morgenstern féle hasznossági függvénnyel $(U)$ rendelkezik, ahol $U$ '>0 és $U^{\prime \prime}<0$. A célja e hasznosság várható értékének maximalizálása. Kétféle biztosított van: csaló, aki a valószínűséggel csal, és tisztességes, aki sohasem csal. A kár $\delta$ valószínűséggel következik be, és természetesen $0<\delta<1$. Szemben Picard (1996) modelljével, feltesszük a csalók egyenletes eloszlását a biztosítók között, és azt, hogy a termékek homogének.

A homogén termékek feltételezése nem tekinthető magas fokú absztrakciónak, hiszen a casco biztosítások érdemben nem különböznek egymástól a magyar piacon, noha a biztosítók igyekeznek egyéb szolgáltatások kínálásával differenciálni a termékek között. $\sigma$-val jelöljük azt a valószínűséget, hogy a biztosító csaló ügyféllel áll szemben - amely az egyenletes eloszlás miatt a csalók arányával egyezik meg -, ami a játék elején ismert a biztosító számára. Szintén elmozdulás az általános modellhez képest, hogy a tanulmányban modellezett, tervezett típusú csalást (planned fraud) végrehajtó csaló nem jelent be valós kárt. Ennek oka, hogy marginális valószínűséggel következhet be valós kár, ha a szerződés létrejöttét követően megtörténik a csalás. Ugyanakkor a valós kár nem lényeges a várható hasznosság szempontjából az optimumban, annak majd a biztosító vélekedésénél lesz szerepe.

Az egyén indulóvagyona $W$, a veszteség legyen $L$. A csaló tevékenység formalizálva a következőt jelenti: A csaló megköti a casco biztosítást $P$ díjon $q$ biztosítási összegre, majd ezután adott valószínűséggel $(\alpha)$ csal, azaz „ellopatja” a $V$ értékű autóját, és valamilyen formában értékesíti. Ez azt jelenti, hogy a gyakorlatot alapul véve vagy eladja a másodlagos piacon, vagy alkatrészként értékesíti, ami lényeges, hogy ezért $\rho V$ összeget kap, ahol $\rho$ értelemszerüen kisebb, mint 1.

Fontos figyelembe venni, hogy Magyarországon a casco biztosításokat szinte kizárólag önrészes formában kínálják a biztosítók (levonásos vagy arányos), méghozzá úgy, hogy adott kár esetén a nagyobb önrészt számítják be. A modellben legyen $D$ a levonás mértéke, függetlenül attól, hogy éppen melyik típusról van szó. Így abban az esetben, ha csal az egyén, a vagyona a következőképpen alakul: $R=W-P+\rho V+(q-D)$, ha sikeresen csal, és $R=W-P+\rho V-M$, ha nem. Itt az $M$ a büntetés mértéke, hiszen a magyar gyakorlatok azt mutatják, hogy nagyon nehéz bizonyítani a csalásokat, ám ha mégis sikerül, akkor a biztosító jogosan követel kártérítést egy büntetőeljárás során, a mentesülése mellett. Természetesen a felülvizsgálatnak is lesz költsége ( $k$ ), ám ez majd a biztosító szempontjából lesz fontos. Tegyük fel most, hogy 
egy adott szerződést vizsgálunk, azaz rögzítjük a $q$-t és a $P$-t. Ha valaki tisztességes, azaz nem jelent be fiktív kárt, akkor a vagyona $R=W-P+V$ lesz. Itt fontos megjegyezni, hogy ezen változók, melyek a magyar csalási szituáció leképezéséből következnek, nem szerepelnek az általános modellben, noha érdemben befolyásolják a játék kimenetelét, a modell eredményeit, és ezáltal a magyar casco-piacra tehető megállapításokat. Legyen végül a sikeres csalás valószínüsége a modellben $\theta$, ami alatt azt értjük, hogy a csalás nem kerül felderítésre, és a csaló megkapja a biztosítási összeget.

A fenti feltételek következtében a csaló akkor csal, ha a csalásból származó várható haszna nagyobb, mint abban az esetben, ha nem csal:

$$
U(W-P+V)<\theta U(W-P+\rho V+(q-D))+(1-\theta) U(W-P+\rho V-M)
$$

Legyen $\theta$ az a sikeres csalási valószínűség, amely mellett a csaló éppen indifferens a csalást illetően. Ez az érték egyszerủ átrendezéssel adódik, ha fenti egyenlőtlenséget egyenlet formájában tekintjük.

$$
\hat{\theta}=\frac{U(W-P+V)-U(W-P+\rho V-M)}{U(W-P+\rho V+(q-D))-U(W-P+\rho V-M)}
$$

Mint fentebb is említettük, tekintsük rögzítettnek a $q$-t és $P$-t, így ebben az esetben a $\theta$ $=\theta(V, D)$, azaz az indifferens csalási valószínűség csak az autó értékétől és az önrésztől függ, hiszen a fenti egyenlőtlenségben szereplő többi változó eleve exogén $(W, M)$.

Az indifferens sikeres csalás valószínűsége, ahogy a képlet is mutatja, növekvő függvénye az önrésznek, hiszen a nagyobb önrész csökkenti a várható hasznot, azaz nagyobb sikervalószínűség kell, hogy indifferens legyen a csaló.

\section{Rendkívül nehéz a csalást felszínre hozni.}

Ami a sikeres csalás $(\theta)$ valószínűségét illeti, az általános Picard-modellben és más elméleti modellekben is 0 -val egyenlő, ha a biztosító felülvizsgált. Bár a tanulmány egy elméleti modell taglalására épül, fontos kiemelni a sikeres csalás valószínűségével kapcsolatos gyakorlati vonatkozást. Ahogyan az irodalmi áttekintésben említettük, Caron és Dionne (1997) tanulmányukban megmutatták, hogy a csalások mindössze 33 százalékát képesek csak a biztosítók sikeresen kideríteni, ha felülvizsgálnak. Magyarországon ugyan konkrét számadatokkal nem rendelkezünk ezen esemény valószínűségét illetően, kétségtelen azonban, hogy rendkívül nehéz a csalást felszínre hozni, még ha a biztosító tudja vagy gyanítja is a tisztességtelen viselkedést. Ezért legyen a modellben a biztosító felülvizsgálati valószínűsége $p$, annak valószínűsége pedig, hogy sikeresen felderíti a csalást, ha felülvizsgált, legyen $c$. Így alkalmazva a teljes valószínűség tételét a sikeres csalás valószínűsége $(\theta)$ éppen egyenlő 1-cp-vel.

\section{A játék felírása}

Mielőtt megvizsgálnánk a felülvizsgálati játék menetét, és részleteznénk az egyensúlyi viselkedéseket, röviden szót ejtünk a modell játékelméleti megalapozásáról. A vizsgált szituáció játékelméleti keretben nem tökéletes információs játékként modellezhető gyakoribb nevén Bayesi-játék -, amelynek sajátossága, hogy a játékosok nem ismerik teljes egészében a játékot, a stratégiahalmazokat és a kifizetőfüggvényeket, szemben a tökéletes információs játékokkal. Az ilyen típusú játékok felírását a Harsányi János által megalkotott modellben szokás mindmáig elvégezni (lásd bővebben Pintér 2004). A tanulmány felülvizsgálati játékának úgymond időbeli lefolyása a következő:

- Elöször is a természet választ egy típust a játékosok típushalmazaiból, azaz eldönti, hogy tisztességes vagy pedig tisztességtelen az ügyfél ( $\sigma$ valószínűséggel).

- A szerződő eldönti, hogy tesz-e kárbejelentést, azaz választanak egy cselekvést a stratégiahalmazaikból. A csalók $\alpha$ valószínűséggel jelentenek be kárt, ha az nem következett be. A tisztességes ügyfelek persze sohasem csalnak.

- Legvégül pedig a biztosító dönt, hogy amennyiben bejelentett egy kárt a szerződő, akkor azt felülvizsgálja, vagy nem, $p$ és 1- $p$ valószínűséggel.

Ez a játék így már egy teljes, de nem tökéletes információs játék, amelyet extenzív formában értelmezünk, és fel lehet írni a játékhoz tartozó játékfát. Célunk tehát e játéknak megkeresni a tökéletes Bayesi-egyensúlyát, amely keresés során legtöbbször nem lehet használni a visszafelé indukciót, mint például a teljes információs esetekben. Így ebben az esetben a Bayesi-egyensúlyt nehezebb megtalálni, mint a részjáték tökéletes egyensúlyt a teljes információs esetekben. Elsőként azonban érdemes kitérni a jelzéses játékokra, amely egy speciális alkalmazási területe a tökéletes Bayesi-egyensúlynak. Forgó et al. (2005) egy olyan egyszerü munkaerő-piaci jelzéses játékot ismertet, ahol két szereplö van, a munkaadó és a munkavállaló.

Ez a modell tökéletesen megfelel a tanulmányban ismertetett szituációra, hiszen eszerint a természet kiválasztja a típust, az adott típus üzenetet választ a lehetséges halmazból, a másik játékos megfigyeli ezt az üzenetet, és választ egy cselekvést a saját cselekvés halmazából, majd pedig megtörténnek a kifizetések, akárcsak az előbbiekben felírt modellben. Analóg módon, a munkaerő-piaci szituációban is csak a munkavállalónak van többelemű típushalmaza, így ez a keret alkalmazható a tanulmány csalási szituációjára is.

Ezek után lássuk az 1. ábrán szereplő felülvizsgálati játékfát, hogy tisztább képet kapjunk a játék menetéről: 


\section{1. ábra: A felülvizsgálati játék}

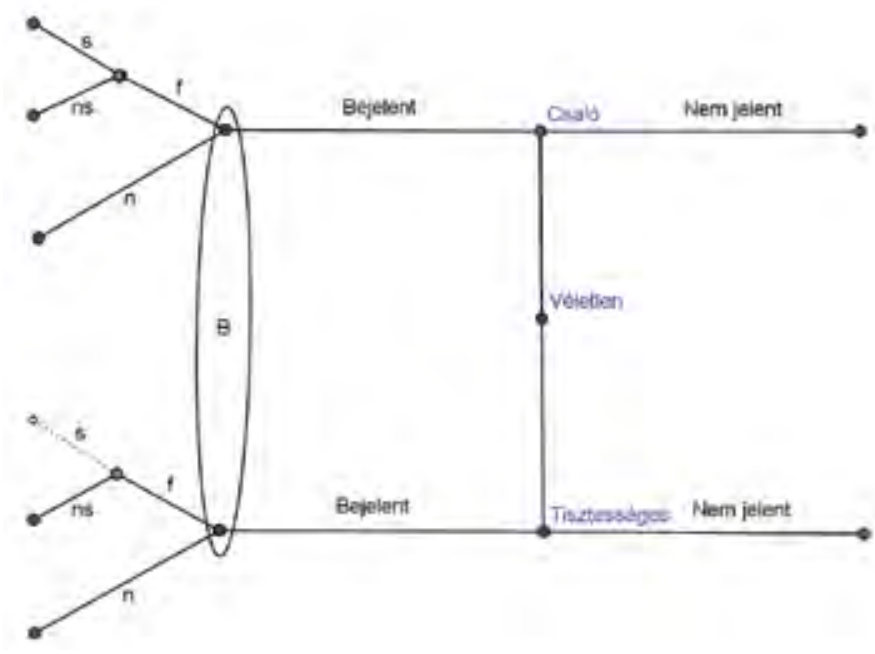

Forrás: saját szerkesztés

A játék menetében elsőként tehát a véletlen választja ki a megfelelő típust a szerződő típushalmazából. Ezt követően a szerződő választ egy stratégiát, majd a biztosító látja az üzenetet, és ezt figyelembe véve dönt. Ebben a játékban természetesen, ha nem érkezik kárigény, akkor nem folytatódik a játék, a szerződő hasznossága a kifizetett díjjal csökken, a biztosító vagyona pedig - a biztosítási esemény bekövetkezésének hiányában - növekszik. A másik esetben, amikor kárbejelentés történik, a biztosítónak kell döntenie, hogy felülvizsgálja-e a szerződést $(f)$, vagy pedig nem $(n)$.

Folytatva a játékot, ha a biztosító nem vizsgálja felül a szerződést, akkor kénytelen kifizetni a kárt (adott esetben a biztosítási összeget). Míg ha a felülvizsgálat mellett dönt, akkor sem biztos, hogy felderíti a csalást. Éppen emiatt felülvizsgálat esetén is lehet sikeres (s) a folyamat, de lehet, hogy nem sikerül (ns) bizonyítani a csalást. Az alsó ágon - amikor tisztességes ügyféllel áll szemben a biztosító - is dönthet a biztosító a felülvizsgálat mellett, ha gyanúsnak ítéli a bejelentést, feltesszük azonban, hogy ekkor csakis sikertelen lehet a felülvizsgálat, éppen ezért jelöltem szaggatott vonallal azt az ágat.

Miután megismertük a játék struktúráját, és elméleti oldalról körüljártuk a kérdést, elérkeztünk a megoldás részletezéséhez.

A felülvizsgálati játék extenzív formája és a megoldás

Felhasználva a korábban bevezetett jelöléseket, kiegészíthetjük az előzőekben felírt játékfát a kifizetésekkel és a valószínűségekkel, ennek alapján elindulhatunk az egyes szereplők viselkedéseit vizsgálva. Ezt láthatjuk a 2. ábrán, ahol a játékfa már a kifizetéseket is tartalmazza:

\section{2. ábra: A felülvizsgálati játék kifizetésekke}

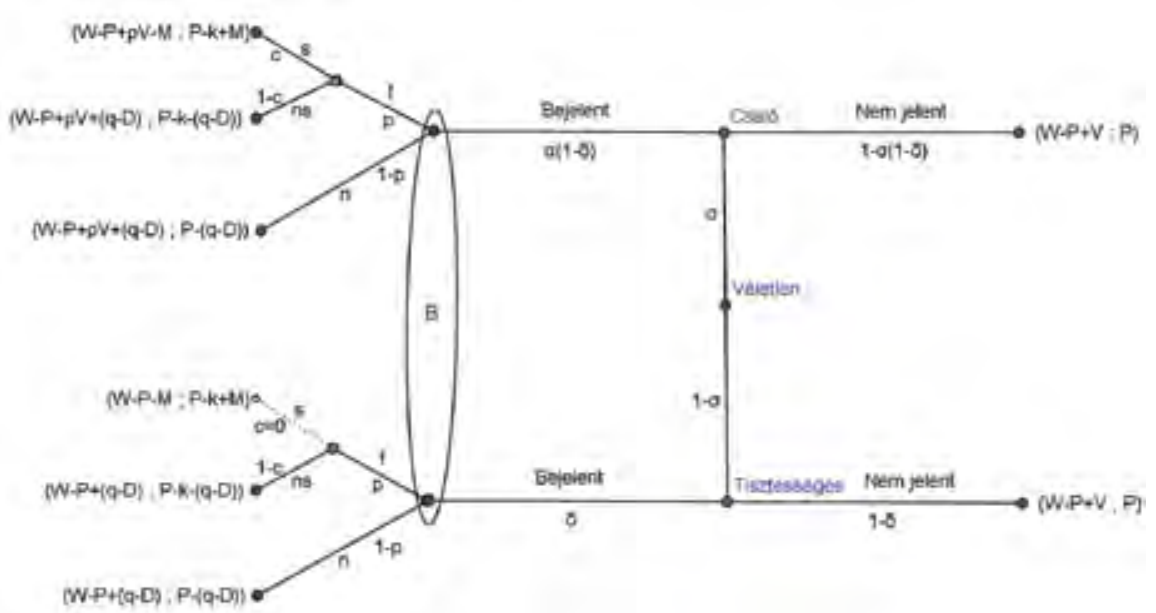

Forrás: saját szerkesztés

A feladat elsőre bonyolultnak tűnhet, látva a sokrétű jelölési rendszert és struktúrát, azonban ez nincs így. Fontos kiemelni, hogy az ábrán a kifizetések esetében a vagyon $(R)$ van szerepeltetve, ezt a döntéshozók a már bevezetett hasznossági függvénybe $(U)$ helyettesítik, azaz konkáv transzformálják, és céljuk természetesen most is az $(E U(R))$ várható hasznosság maximalizálása.

Az ábrán nem szerepel ugyan, de korábban bevezettük a sikeres csalás valószínűségére a $\theta$ jelölést, amelynek értéke megegyezett 1-cp-vel. Ahogy a játékfa mutatja, akkor sikeres a csalás, ha a biztosító felülvizsgál ( $f$ ), de nem sikerül (ns) bebizonyítania a szerződő csalását, illetve ha nem vizsgál felül $(n)$. Azaz $\theta=p(1-c)+1-p=1-c p$, mint azt az előzőekben is beláttuk.

Ezek után elsőként lássuk ismét a döntéshozó várható hasznosságát, akinek $\alpha$ a döntési változója:

$$
E U=\alpha(U(W-P+\rho V+(q-D))+(1-\theta) U(W-P+\rho V-M))
$$$$
+(1-\alpha) U(W-P+V)
$$

Innen az $\alpha$ :

$$
\alpha=\left\{\begin{aligned}
1, & \theta>\hat{\theta}(V, D) \\
0, & \theta<\hat{\theta}(V, D) \\
{[0,1], } & \theta=\hat{\theta}(V, D)
\end{aligned}\right.
$$

Ez nem jelent mást, mint hogy ha nagyobb a sikeres csalás valószínűsége, mint az indifferens valószínűség, akkor $\alpha=1$ valószínűséggel csalni fog a döntéshozó, ha kisebb, akkor nem fog csalni, ha pedig éppen egyenlő, akkor a csalás valószínűsége a $[0,1]$ intervallumban van. Ami a biztosító döntési pontját illeti, a felülvizsgálat valószínűségén ( $p$ ) keresztül van 
befolyása a játék menetére, amellyel célja - közgazdasági értelemben - a kárkifizetési költségek minimalizálása. Ezen a ponton elméleti szinten kérdéses, hogy a biztosító képes-e elköteleződni a felülvizsgálat iránt, avagy sem, hiszen ez gyökeresen módosítja a megoldást és az eredményeket is. Ahogyan az irodalmi áttekintés már említette, az elköteleződés hiánya jelentős jóléti veszteséget okoz, valamint a magas biztosítási díjak akár a piac megszűnését is eredményezhetik, ennek ellenére a gyakorlatban a legtöbb helyen ez érvényesül. Nincs ez másképp Magyarországon sem.

Ebben az esetben a biztosító egyensúlyi viselkedése a legjobbválasz-függvényt jelenti a csaló viselkedésére. Ahhoz azonban, hogy a jelzéses játéknak létezzen tökéletes Bayesi-egyensúlya, a második döntéshozónak kell, hogy legyen vélekedése arról, hogy mely típussal áll szemben (Forgó et al., 2005), amit a következőképpen határoz meg.

$$
\mu\left(t_{i} \mid s_{j}\right)=\frac{p\left(t_{i}\right)}{\sum_{t_{r} \in \theta_{i}} p\left(t_{r}\right)}
$$

Ezt a feltevést nevezik Harsányi-doktrínának, amely szerint tehát létezik egy a priori eloszlás a $\Theta$ típustéren (ez esetünkben a $\sigma$, ami csalók arányát jelenti). Ez köztudott, és a vélekedéseket ebből a Bayes-tétel segítségével számoliák (Forgó et al., [2005]). Értelmezve a felírt összefüggést, a biztosító kialakít egy vélekedést arról, hogy melyik típussal $\left(t_{i}\right)$ áll szemben, ha kapott egy $s$ üzenetet. Legyen $\pi$ a hamisan bejelentett kár valószínűsége, ebből következően annak valószínűsége, hogy csalóval áll szemben a biztosító, ha kárbejelentést kapott, tekintve hogy a tisztességes ügyfelek sosem csalnak. Ez a játékfa alapján a következő:

$$
\mu\left(t_{i} \mid s_{i}\right)=\pi=\frac{\alpha \sigma(1-\delta)}{\alpha \sigma(1-\delta)+(1-\sigma) \delta}
$$

A tört számlálójában annak valószínűsége áll, hogy egy csaló hamis kárt jelent be, míg a nevező második tagja jelöli $((1-\sigma) \delta)$ a valós kárt a tisztességes ügyfél részéről. Fontos feltétel, hogy a valószínüségek összege 1 kell, hogy legyen, azaz $\sum_{\ell_{i} \in \varepsilon_{i}} \mu\left(t_{i} \mid s_{j}\right)=1$. Ez teljesül, hiszen annak valószínűsége, hogy tisztességes ügyféllel van dolga a biztosítónak, ha kárbejelentést kapott, az $1-\pi=\frac{(1-\sigma) \delta}{\left(1-\sigma^{\prime}\right)(1-\sigma)^{\prime \prime}}$

Megjegyezzük, hogy ezen a ponton eltérünk az általános modelltől a már említett eltérő feltételezés miatt, ami a csaló viselkedését illeti. Tekintve a számos változtatást, a játék menete megegyezik ugyan a Picard (1996) által bemutatott modellel, azonban az eredmények, optimális viselkedések nem, köszönhetően az eltérő, célunk szerint a magyar gyakorlatot jobban megragadó feltétel rendszernek.

A biztosító tehát ezen vélekedések figyelembevételével maximalizálja a várható kifizetését a játékban, azonban esetünkben ez a kiadások minimalizálását jelentse, hiszen a két dolog ekvivalens, de most megkönnyíti a feladatot. Emellett éljünk azzal az egyszerüsítési lehetőséggel, hogy a minden esetben beérkező $P$ díjat hagyjuk figyelmen kívül, hiszen ezzel semmit sem veszítünk, és valóban szigorú értelemben vett kiadásai lesznek csak a biztosítónak. Ha a felülvizsgálati játékfát nézzük, a biztosítónak csak kárbejelentés esetén van döntési szituációja (bekeretezett halmaz), így a másik ág számára úgymond semleges és kevésbé releváns. A biztosító kiadása így a következőképpen írható fel, ami persze éppen -1-szerese a játékfán szereplő értékeknek:

$$
\hat{C}= \begin{cases}\pi c(\mathrm{k}-\mathrm{M}), & \text { ha } f+s \\ (1-\pi)(\mathrm{k}+(\mathrm{q}-\mathrm{D}))+\pi(1-c)(\mathrm{k}+(\mathrm{q}-\mathrm{D})), & \text { ha } f+n s \\ q-D & \text { különben }\end{cases}
$$

Az első eset egyértelmű, felülvizsgálat esetén akkor sikeres a biztosító, ha hamis kárt jelentettek be $(\pi)$, és sikeresen vizsgáltak felül (c). Ez esetben a kifizetés $k-M$, azaz feltettük, hogy a csaló büntetését teljes egészében megkapja a biztosító. A második eset valamivel bonyolultabb, ha van felülvizsgálat, az kétféleképpen lehet nem sikeres: vagy valódi a kár $(1-\pi)$, és akkor feltesszük, hogy 0 valószínűséggel sikeres az eljárás $(c=0, a z a z(1-c)=1)$, vagy pedig hamis a kár, és nem sikerül felderíteni, ez a $\pi(1-c)$ valószínűség. Mivel feltesszük azt is (talán kicsit leegyszerüsítve), hogy a tisztességes ügyfél valódi kárbejelentését ért jogtalan megvádolás - ilyen például a jó hírnév megsértése, amelyért lehet kártérítési pert indítani - nem jár pluszköltséggel, így a két kifizetés megegyezik $(k+(q-D))$, azaz a valószínúségeket össze lehet vonni: $(1-\pi)(k+(q-D)+\pi(1-c)$ $(k+(q-D))=(1-\pi c)(k+(q-D))$.

A harmadik eset triviális, ha nincs felülvizsgálat, a biztosító kifizeti a $(q-D)$ összeget. Összegezve az eseteket, a biztosító költsége a következő lesz:

$c^{\prime}:=p(\pi c(k-M)+(1-\pi c)(k+(q-D)))+(1-p)(q-D)=(q-D)+p(k-\pi c((q-D)+M))$

Ezt pedig az egyensúlyi felülvizsgálati valószínűség szerint $(p)$ minimalizálja, azaz:

$$
p=\left\{\begin{array}{cc}
0, & k>\pi c((q-D)+M) \\
1, & k<\pi c((q-D)+M) \\
{[0,1] .} & k=\pi c((q-D)+M)
\end{array}\right.
$$

Miután megkaptuk mind a biztosított, mind pedig a biztosító optimális viselkedésére vonatkozó feltételeket ( $\alpha$ és $p$ ), a következő állítást tehetjük:

1. állítás. A tipikus magyar casco biztosítási csalást modellező felülvizsgálati játék megoldása a következőképpen alakul:

$$
\begin{gathered}
p=0 \text { ès } \alpha=1, \text { ha. } k>\frac{\sigma(1-\delta) c(i q-D)+M)}{\sigma(1-\delta]+(1-\sigma) \phi} \\
p \in\left[0, \frac{1-\hat{\theta}}{c}\right] \text { és } \alpha=1, \text { ha } k=\frac{\sigma(1-\delta) c((q-D)+M)}{\sigma(1-\delta)+(1-\sigma) \delta} \\
p=\frac{1-\hat{\theta}}{c} \text { és } \alpha=\frac{(1-\sigma) \delta k}{\sigma(1-\delta)((q-D)+M-k)} \text {, ha } k<\frac{\sigma(1-\delta) c((q-D)+M)}{\sigma(1-\delta)+(1-\sigma) \delta}
\end{gathered}
$$


Eszerint ha a biztosító felülvizsgálati költsége magasabb, mint a $\pi c((q-D)+M) a z \alpha=1$ esetben, akkor nincs felülvizsgálat, és így a biztosított $\alpha=1$ valószínűséggel csal. Korábban kifejtettük, hogy a sikeres csalás valószínűsége $\theta=1-p c$, ez az, ami szerint a 4. egyenletben a csaló dönt. Így átrendezve és tekintve azt a $\theta$-t, amelynél a biztosított éppen indifferens, p-re adódik a (1- $\theta) / c$ összefüggés. Azaz ha a biztosító költsége megegyezik az előbb említett $\pi c((q-D)+M)$-vel (az $\alpha=1$ esetén), akkor a csaló $\alpha=1$ valószínüséggel csal, ha a biztosító legfeljebb $(1-\theta) / c$ valószínűséggel vizsgál felül. A harmadik eset tehát az egyetlen, amelyben a csaló $a<1$ valószínüséggel csal.

\section{A modell következtetései és további megfontolások}

Az elözőekben felírt modell megoldása után a következtetések levonása maradt még hátra. Elsőként nézzük a 3. és a 4. egyenleteket, amelyek a csaló döntését írják le:

$E U=\alpha(U(W-P+\rho V+(q-D))+(1-\theta) U(W-P+\rho V-M))+(1-\alpha) U(W-P+V)$

$$
a=\left\{\begin{aligned}
1, & \theta>\hat{\theta}(V, D) \\
0, & \theta<\hat{\theta}(V, D) \\
{[0,1,} & \theta=\hat{\theta}(V, D)
\end{aligned}\right.
$$

Egyrészt könnyen látható, hogy az $\alpha$ növekvő függvénye a $\theta$-nak és $\rho$-nak, míg csökkenő függvénye a $D$-nek $(\partial \alpha / \partial D<0)$. Azaz, ha nagyobb a sikeres csalás valószínüsége, akkor nagyobb valószínűséggel csal a tisztességtelen ügyfél. Másfelől, ha a feketepiacon jól el lehet adni az autót, azaz a $\rho$ értéke elég nagy, akkor szintén motiváltabb a csaló. Vagyis azok a márkák, amelyek keresettebbek, ritkábbak, vélhetően a feketepiacon a reálishoz közeli értéken kelnek el, azaz a $\rho$ magasabb, így ezeknél a márkáknál nagyobb a csalás valószínűsége. Az önrész esetén más a helyzet, a nagyobb önrész csökkenti a csalásból származó hasznot, és így kisebb lesz a csalási valószínűség. Ez azt jelentené, hogy a nagy önrész hatékony eszköze lehet a csalás csökkentésének. Azonban a másik oldalról, ha adott díj mellett nagyobb önrészt kell vállalni, a tisztességes ügyfelek számára kevésbé lesz vonzó a biztosítás. Ha feltesszük, hogy a $\rho$ értéke kellően nagy, azaz a feketepiacon a csaló „jó” pénzt kap az autóért, akkor a magasabb önrész sokkal inkább bünteti a tisztességes ügyfeleket, a csaló szempontjából pedig kisebb a hatása a hasznosságra.

A másik kérdés, amely felmerülhet, ha csak a csaló hasznosságát vizsgáljuk, hogy a büntetés mennyire lehet jó ösztönző? Anélkül, hogy az $M$ értékére bármilyen feltételezéssel is élnénk, látható, hogy az (1- $\theta)$ súlyon keresztül érvényesül a csaló várható hasznosságában. Korábban beláttuk, hogy $1-\theta=c p$, a felülvizsgálat és a sikeresség valószínűségének szorzata. Természetesen nehéz megmondani a $c$ értékét Magyarország esetében, de a biztosítók egyöntetü tapasztalata, hogy a felülvizsgálat esetén sem könnyű felderíteni a csalásokat. Így ha alapul vesszük a már említett 33 százalékos értéket (Caron és Dionne, 1997), és a felülvizsgálat irányába történő elköteleződés hiányát, azaz feltételezünk egy nem túl nagy (de nem is kicsi) $p$-t, akkor kijelenthetö, hogy a tetszőlegesen nagy büntetés sem riasztja el feltétlenül a csalókat. Persze azt a későbbiekben látni fogjuk, hogy a nagyobb büntetés a biztosítóra is hat, növeli a $p$-t, de ezzel együtt is azt mondhatjuk, hogy önmagában a büntetési összeg kellöen magas szintje nem hatékony fellépés a casco-csalással szemben.

Ezek után a biztosító döntését vizsgáljuk, aki a várható költség alapján dönt (7. és 8. egyenlet):

Ebböl a $p$ :

$$
\hat{C}=(q-D)+p(k-\pi c((q-D)+M)) .
$$

$$
p=\left\{\begin{array}{cc}
0, & \mathrm{k}>\pi c((q-D)+M) \\
1, & \mathrm{k}<\pi c((q-D)+M) \\
{[0,1],} & \mathrm{k}=\pi c((\mathrm{q}-\mathrm{D})+\mathrm{M})
\end{array}\right.
$$

Ebben az esetben látható, hogy a $p$ csökkenő függvénye az önrésznek $(\partial p / \partial D<0)$, és természetesen a felülvizsgálati költségnek is $(\partial p / \partial k<0)$. Ez logikus, hiszen adott kárnagyság esetén a nagyobbönrész csökkenti a várható kifizetést (a biztosító hozzájárulását), tehát adott felülvizsgálati költség mellett kevésbé éri meg felülvizsgálni. A költség hatása szintén logikus, minél nagyobb költségigénye van a felderítési folyamatnak, annál kevésbééri meg a biztosítónak a felülvizsgálat.

Érdekes észrevétel továbbá, hogy az önrész hatása nem egyértelmű, hiszen mindkét játékos döntési változója csökkenő függvénye az önrésznek. Azaz direkt módon az önrész növelése csökkenti ugyan a csalási valószínűséget, ugyanakkor a felülvizsgálati valószínűség csökkentésén keresztül indirekt módon növeli azt, hiszen a sikeres csalási valószínűség $(\theta)$ függ a $p$-től $(\theta=1-c p)$, így $\theta$ növelése növeli a csalást, ahogy azt már beláttuk. Korábban azonban azzal érveltünk, hogy amíg a c sikerességi paraméter értéke nem kellően magas, addig a $p$ hatása elgyengül. Ha nem teljes biztonsággal is, de azt mondhatjuk ennek alapján, hogy mivel közvetlenül negatív irányba hat az önrész a csalás valószínűségére, ezért ez minden bizonnyal erősebb a közvetett hatásnál, ami, mint láthatjuk, jelentősen függ $c$ nagyságától, és így az önrész összességében is negatívan hathat a csalási valószínűségre. Érdekes kérdés lehetne, hogy milyen eredő hatása van pontosan az önrésznek, azonban amellett, hogy sok feltételezéssel kellene élnünk, mint említettük, a tisztességes ügyfeleket sokkal inkább bünteti, mint a csalókat - ezáltal nem lehet a csalást meggátoló hatékony eszköz egy bizonyos szint felett -, ezért ennél mélyebben nem foglalkozunk vele.

Lássuk végül az egyensúlyi megoldásból (1. állításban tett megállapítások) adódó következtetéseket:

$$
\begin{gathered}
p=0 \text { és } \alpha=1 \text {, ha } k>\frac{\sigma(1-\delta) \sigma((q-D)+M)}{\sigma(1-\delta)+(1-\sigma) \hat{\delta}} \\
p \in\left[0, \frac{1-\hat{\theta}}{c}\right] \text { és } \alpha=1 \text {, hak } k=\frac{\sigma(1-\delta) c((q-D)+M)}{\sigma(1-\delta)+(1-\sigma) \delta} \\
p=\frac{1-\bar{\theta}}{c} \text { és } \alpha=\frac{(1-\sigma) \delta k}{\sigma(1-\delta)((q-D)+M-k)}, \text { ha } k<\frac{\sigma(1-\delta) c((q-D)+M)}{\sigma(1-\delta)+(1-\sigma) \delta}
\end{gathered}
$$


Nagyon érdekes eredményre jutunk a $c$ paraméter vizsgálatával. Azt már a csaló vizsgálatánál kifejtettük, hogy az $M$ büntetés akkor lehetne igazán hatékony, ha a $c$ értéke kellően nagy lenne. Ebben az esetben látszik, hogy nagyobb $c$-t feltételezve nőne az esélye annak, hogy a felülvizsgálat költsége ( $k$ ) kisebb lesz, mint a $\pi c((q-D)+M)$ az $\alpha=1$

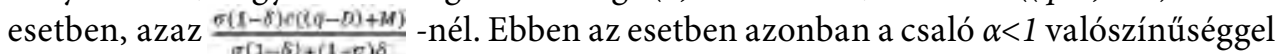
jelent kár, és a biztosító az adott $\theta$ mellett kisebb, de 0 -tól nagyobb valószínűséggel fog felülvizsgálni. Ez tehát azt jelenti, hogy ha nincs elköteleződés, és nem lehet megszüntetni teljesen a csalást, akkor a csalás felderítési hatékonyságának növelése jó eszköz a csalókkal szembeni fellépésben.

A másik vizsgálandó tényező a büntetés. Erről feltettük, hogy egy adott $M$ összeg. Elképzelhető azonban, hogy összefüggésben áll a csalás mértékével, azaz az ellopott autóból származó pénzt kell kifizetnie a csalónak: $M=\rho V$.

Ebben az esetben viszont feltehető, hogy az évek során csökken az $M$, és nyilván a biztosítási összeg is $q$. Ez viszont azt jelenti, hogy fiatalabb autók esetében (nagyobb $q$

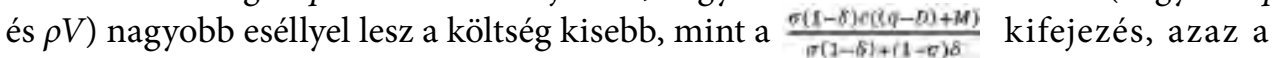
biztosító pozitív valószínűséggel felülvizsgál, a csaló pedig $\alpha<1$ valószínűséggel fog csalni. Másképpen fogalmazva, az $\alpha$ csökkenő függvénye a $V$-nek. Az autó értéke nem csak az évek múlásával változhat, hiszen adott időpontban is eltérnek az autók értékei, így másik érvelés szerint - feltéve, hogy $\rho$ állandó - a nagyobb értékű autók esetében kisebb a csalás valószínűsége, azonban ez a gyakorlatban egyáltalán nem biztos, hogy teljesül. Megjegyzendő azonban, hogy a biztosítók véleménye szerint sem kimondottan a nagy értékű autókra jellemző e csalástípus (www.alkuszbiztositas.hu, 2001), így e kérdést is célszerű lenne alávetni gyakorlati vizsgálatnak.

Összefoglalva a tett megállapításokat, az alkotott modell eredményei a következők:

2. állítás. A magyarországi casco-csalás egyik leggyakoribb fajtájára alkotott elméleti modelljének eredményei szerint:

- $\quad$ Az $\alpha$ növekvő függvénye $\theta$-nak és $\rho$-nak, eszerint a kedveltebb márkák esetében nagyobb a csalás valószínűsége.

- $\quad A z$ önrész direkt hatása negatív a csalás valószínűségére, azaz $\partial \alpha / \partial D<0$.

- A $\quad$ csökkenő függvénye a felülvizsgálati költségnek és az önrésznek is, ezáltal az önrész indirekten is hat $\alpha$-ra, tehát a hatása nem egyértelmü:. $D \gg p \gg \theta(=1-c p) \times \Rightarrow$.

- A büntetés az 1- $\theta$ súlyon keresztül érvényesül a csaló várható hasznosságában, de 1- $\theta=c p$, vagyis a nagy büntetés önmagában nem hatékony ösztönzö, fontos a csalás bizonyítására tett kísérlet sikerességének növelése (c).

- Magasabb $c$ paraméter esetén a felülvizsgálat költsége kisebb lesz, mint a $\pi c((q-D)+M)$ vagyis a sikeres felülvizsgálat hatása kétszeresen negatív a csalási valószínűségre.

- Ha $M=\rho V$, akkor $M$ és $q$ csökken az évek során, ebből következően a $\pi c((q-D)+M)$ is csökken, ami pedig implikálja a felülvizsgálati valószínűség csökkenését. Ebből következően a fiatal autóknál jobban megéri felülvizsgálni.

- $\quad$ Ha $M=\rho V$, akkor a magasabb értékủ autók esetén kisebb lesz az $\alpha$, azaz $\partial \alpha / \partial V<0$

- Ennekértelmében pedig nem kimondottan a nagy értékű autókra lesz jellemző a csalás.

Ami az elméletben alkotott modell következtetéseit illeti, azt gondolom, használható keretet, fontos összefüggéseket és jól tesztelhető predikciókat kínál, egyúttal választ ad arra, hogy melyek a csalásra ható legfontosabb tényezők, és azok milyen irányból hatnak a csaló viselkedésére. Választ kaptunk az önrész, a büntetés nagysága, a sikerességi paraméter, a felderítés költsége vagy az autó másodpiaci értékének hatására az egyes döntési változók esetében. Így összességében elmondható, hogy az elméleti modell megalkotása hasznos és releváns információkat adott a kérdéskör tekintetében.

\section{Összefoglalás}

Tanulmányomban a biztosítási csalások elméleti modellezésével foglalkoztam. Kifejtettem, hogy a biztosítási piacok kiváltképp különböznek szerte a világon, így a csalási típusok eltérőek. Ebből kifolyólag a tanulmány célja az volt, hogy a magyar gépjármü-biztosítási piacon fellelhető „tipikus” csalást modellezze, azaz azt az esetet, amikor egy egyén casco biztosítást köt, majd szándékosan „ellopatja” az autóját, kárbejelentést tesz, és a feketepiacon az autót értékesíti.

A tanulmány szempontjából lényeges irodalmak áttekintését követően rátértem a gépjármü-biztosításokra. Itt kiemeltem a termékek különbözőségét és a csalások sokféleségét, majd röviden szót ejtettem a magyar gépjármü-biztosítási piacról. Itt részleteztem a casco biztosítási piacot, és néhány számadattal szemléltettem a csalások által okozott veszteségeket. A 90-es évek legnagyobb casco-csalásának leírásával mutattam be azt az esetet, amelyet a tanulmány modellez.

\section{| Az önrész hatása nem egyértelmü.}

A tanulmány legfőbb egyéni hozzájárulása a fent is megfogalmazott és mai napig Magyarországon gyakran véghezvitt csalás elméleti modelljének megalkotása volt, amely a Picard (1996) által bemutatott általános csalást leíró modellre építve egy, a feltételeiben a magyar casco-csalási gyakorlatot megragadó keretrendszert hozott létre. A háromszintű játék megoldásaként kapott eredmény több szempontból tanulságos volt. Egyrészt kiemeltem, hogy az önrész hatása nem egyértelmü, ugyanis több irányból hat a csaló optimális viselkedésére, tekintve, hogy a biztosító felülvizsgálati valószínűségét is csökkenti. Másrészt beláttam, hogy az értéktartóbb márkák - amelyek eladhatóbbak a másodlagos piacon - növelik a csalás valószínűségét. Arra jutottam továbbá, hogy a büntetés hatása meglehetősen gyengül, hiszen a sikeres felderítés valószínűsége mi- 
att - amely meglehetősen alacsony a gyakorlatban - kis súlyt kap a csaló hasznossági függvényében. Ami a csalás sikeres felderítési valószínűségét illeti, nemcsak a büntetés oldaláról hat a csalás valószínűségére, hanem nagyobb eséllyel éri meg a biztosítónak felülvizsgálni, így ez tekinthető a leghasznosabb eszköznek a csalások mértékének csökkentésére, bár több helyen hangsúlyozta a tanulmány, hogy e változó növelése meglehetősen nehéz gyakorlati oldalról

\section{IA csalás valószínúsége növekszik az autó életkorának növekedésével.}

Bevezetve azt a feltevést, hogy a büntetés az eladott autó értékével egyezik meg, megállapítható, hogy a sikeres csalás valószínűsége növekszik az autó életkorának növekedésével, továbbá fontos megállapítás, hogy a csalás nem kimondottan a nagy értékü autók esetén jellemző csupán.

Úgy gondolom, a tanulmány jó alapja lehet a további vizsgálódásoknak. Alapvetően két irányba érdemes továbblépni: egyrészt az elméleti modellt lehet finomítani olyan értelemben, hogy minél hasznosabb következtetéseket lehessen levonni belöle. Másrészt megfelelő adatok birtokában egy empirikus elemzéssel lehetne igazolni az elméletben megfogalmazott feltevéseket, illetve megcáfolni a megállapításokat. Nem szükségszerü ugyanis, hogy egy elméleti modell, amely úgymond laboratóriumi eset, teljesüljön a gyakorlatban, azonban ha ez mégis megtörténne, ebben az esetben a tanulmány jó alapja lehet a biztosítási csalások megfelelő kezelésének, aminek társadalmi szinten véve is lenne hozzáadott értéke.

\section{IRODALOMJEGYZEKK}

2009. évi LXII. törvény: a kötelező gépjármü-felelösségbiztositáśról.

Ágoston Kolos (2004): Hogyan hat a bizonytalanságés a vevőkkör nagysága együttesen az árakra? PhD. értekezés. 2004 , Budapest. Andersson, F. - Skogh, G. (2003): Quality, self-regulation, and competition: the case of insurance. Insurance: Mathematics and Economics, 32 pp. 267-280.

http://dx.doi.org/10.1016/s0167-6687(03)00111-2

Artís, M. - Ayuso, M. - Guillén, M. (1999): Modelling different types of automobile insurance fraud behaviour in the Spanish Economics, 24 pp. 67-81

Bond, E. W. - Crocker, K. I. (1997): Hardball and the Soft Touch: The Economics of Optimal Insurance Contracts With Costly State Verification and Endogenous Monitoring Costs. Journal of Public Economics, 63 pp. 239-264.

http://dx.doi.org/10.1016/50047-2727(96)01594-0

Biztositási Szemle (2012): Növekvő fizetésképtelenség a casco-piacon Biztositási Szemle (online kiadás) 2012. 03. 08. URL: www.

. http://www_biztositaszemle hu/cikk/hazaihirek/gazdasag/evente_10_milliardok_kerulnek_biztositasi_csalokhoz $5014 \mathrm{htm}$ (Letöltve: 2016.01.03.)

Biztositasi Szemle (2015b): Az adomérsekles novel né a casco biztositások számát. Biztositási Szemle (online kiadás) 2015. 10. 19. URL http://www.biztositasiszemle.hu/cikk/hazaihirek/gazdasag/az_adomersekles_novelne_a_casco-biztositasok_szamat_.5203. html (Letöltve: 2016.01.03.)

.

Assurances, 64(4) pp. 567-578.
Crocker, K.J. - Morgan, J. (1998): Is Honesty the Best Policy? Curtailing Insurance Fraud Through Optimal Incentive Contracts.

Journal of Political Economy, 106(2): $355-375$.
http://dx.doi.org/10.1086/250012 Crocker, K. J. - Tennyson, S. (1999): Costly State Falsification or Verification? Theory and Evidence from Bodily Injury Liability
Claims, in: C. Laberge-Nadeau and G. Dionne, eds., Automobile Insurance: Road Safety, New Drivers, Risks, Insurance Fraud and Regulation. Kluwer, Boston

- $615-4058-8$ - 6

http://www deloitte.com/assets/Dróngramok a biztositási szektorban. Deloitte Magyarország Kft. URL:

ve:2013.03.17)

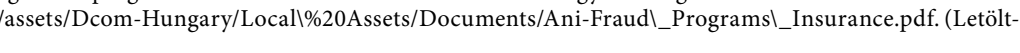

Derrig, R. A. - Weisberg, H. I. - Chen, X (1994): Behavioral Factors and Lotteries Under No-Fault With a Monetary Threshold:
A Study of Massachusetts Automobile Claims. Journal of Risk and Insurance, 61 pp. $245-275$. Donne, G. - Gagné, R. (2001): Deductible Contracts Against Fraudulent Claims: An Empirical Evidence in Automobile Insurance. Review of Economics and Statistics, 83(2), pp. 290-301.

Dionne, G. - Gagné, R. (2002): Replacement Cost Endorsement and Opportunistic

(213), pp. 213-230.

Berger, M. S. - Davis, E. B. - Weiner, J - Boyer, E. G. - Ubel, P. A. (1997): Confidentiality and health insurance fraud. Archives of Internal Medicine,157(5), pp. 501-504.

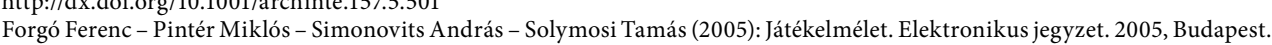
Generali (2010): Továbbra is jelentös mértékủ kárt okoznak a biztositási csalások. OrientPress Hírügynökség (online kiadás) 2010.0123. URL h btt

Holmström, B. (1979): Moral Hazart and Observability. The Bell Journal of Economics. 10(1), pp. 74-91.

http://dx.doi.org/10.2307/3003320

MABISZ (2015): Magyar Biztositók Évkönyve. Magyar Biztositók Szövetsége (online kiadás.

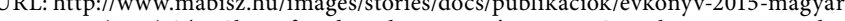

(1992), pp. 28-32.

Picard, P. (1996): Auditing Claims in Insurance Markets with Fraud: The Credibility Issue. Journal of Public Economics, 63(1). pp. $27-56$

http://dx.doi.org/10.1016/0047-2727(95)01569-8

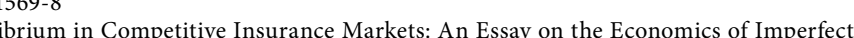
Information. The Quarterly Journal of Economics. 90(4) pp. 629-649.

Shavell, S. (1979): On Moral Hazard and Insurance. Quarterly Journal of Economics. 93(4) pp. 541-562.

http://dx.doi.org/10.2307/1884469

SPSS: Decision Management for Claim. SPSS Clementine Consulting. URL: http://www.spss.hu/termekek-es-megoldasok/ predictiveclaims.html. (Letöltve: 2013.03.17)

hy Fraud Plagues America's Health Care System. Westview Press, Boulder.

Spindler, M. - Winter, J. - Hagmayer, S. (2012): Asymetric Information in the Market for Automobile Insurance: Evidence from Germany. Munich Center for the Economics of Aging Discussion Papers

http://dx.doi.org/10.2139/ssrn.2150044

The ttp://dx.doiorg/10.1111/1539-6975.00024

Weisberg, H. I. - Derrig, R. A. (1991): Fraud and Automobile Insurance: A Report on the Baseline Study of Bodily Injury Claims in Massachusetts. Journal of Insurance Regulation, 9 pp. 497-541.

Weisberg, H. I. - Derrig, R. A. (1992): Massachusetts AP. 497-541. A Ril 10 pp. $384-440$

Weisberg H.I. - Derrig, R. A. (1998): Quantitative methods for detecting fraudulent automobile bodily injury claims.. AIB Cost Containment/Fraud Filing (3) pp. 49-82.

Biztositási csalások - kifizetődő? Alkuszbiztositás (online kiadás). URL: http://www.alkuszbiz-

\section{HIVATKOZÁSOK}

A tanulmány egy átdolgozott változata korábbi Tudományos Diákköri Konferenciára írt dolgozatomnak, amely első helyezés ért el a 2015-ös, XXXII OTDK Közgazdaśástudományi szelciójának Mikro-modellezés tagozatában. 